\title{
Influence of rumen ammonia concentration on the rumen degradation rates of barley and maize
}

\author{
BY J. ODLE AND D. M. SCHAEFER* \\ Department of Meat and Animal Science, University of Wisconsin-Madison, \\ Madison, Wisconsin 53706, USA
}

(Received 17 June 1986 - Accepted 26 August 1986)

\begin{abstract}
1. Four rumen-cannulated steers were given barley and maize diets supplemented with graded levels of an ammonium acetate solution.

2. Animals were fed hourly from automatic feeders and water consumption was controlled to achieve steady-state conditions in the rumen.

3. Dacron bags containing rolled barley or ground barley were incubated in the rumen of barley-fed steers, while ground maize and autoclaved maize were incubated in the rumen of maize-fed steers.

4. Fractional degradation rates of dry matter were estimated for each cereal substrate incubated using a single-pool exponential decay model.

5. No differences in degradation rate due to the method of feed processing were detected; however, barley was degraded at a faster rate than maize. Furthermore, the minimum rumen ammonia-nitrogen concentration required to maximize the degradation rate of barley $(125 \mathrm{mg} / 1)$ was greater than that required to maximize the degradation rate of maize $(61 \mathrm{mg} / \mathrm{l})$.

6. These results indicate that the optimal $\mathrm{NH}_{3}-\mathrm{N}$ concentration required to maximize the rate of grain digestion in the rumen is influenced by the chemical or structural characteristics of the grain.
\end{abstract}

Ammonia is the main nitrogen source for rumen bacteria (Bryant \& Robinson, 1962) while amino- $\mathrm{N}$ is the main $\mathrm{N}$ source for rumen protozoa (Coleman, 1979). The requirement for $\mathrm{NH}_{3}-\mathrm{N}$ (considered to be the sum of $\mathrm{NH}_{3}-\mathrm{N}$ and $\mathrm{NH}_{4}-\mathrm{N}$ ) by the mixed microbial population of the rumen can be described by the optimal rumen $\mathrm{NH}_{3}-\mathrm{N}$ concentration, which can be defined as the minimum concentration of $\mathrm{NH}_{3}-\mathrm{N}$ necessary to support maximum bacterial growth rates. This definition is consistent with the use of specific growth rate (Schaefer $e t$ al. 1980), rate of microbial protein synthesis (Satter \& Slyter, 1974), rumen outflow rate of microbial protein (Hume et al. 1970; Allen \& Miller, 1976), microbial protein concentration (Slyter et al. 1979; Kang-Meznarich \& Broderick, 1981) and ${ }^{15} \mathrm{NH}_{4}$ incorporation rate (Nikolic et al. 1975) as dependent variables for determining an $\mathrm{NH}_{3}-\mathrm{N}$ requirement. These variables contrast with the rate of dry matter disappearance (Mehrez et al. 1977; Ortega et al. 1979) and concentration of total volatile fatty acids (VFA) (Slyter et al. 1979), variables which also have been used to define optimal rumen $\mathrm{NH}_{3}-\mathrm{N}$ concentrations but which reflect the effects of $\mathrm{NH}_{3}-\mathrm{N}$ concentration on the degradative activities of the rumen microbial population.

The lack of agreement between estimates of $14 \mathrm{mg} \mathrm{NH}_{3}-\mathrm{N} / 1$ (Schaefer et al. 1980) and $50 \mathrm{mg} \mathrm{NH}{ }_{3}-\mathrm{N} / 1$ (Satter \& Slyter, 1974) for optimal rumen $\mathrm{NH}_{3}-\mathrm{N}$ concentration based on microbial growth and an estimate of $194 \mathrm{mg} \mathrm{NH}_{3}-\mathrm{N} / 1$ based on barley dry matter disappearance from dacron bags (Mehrez et al. 1977) demands an explanation. Mehrez et al. (1977) suggested that the estimate of optimal rumen $\mathrm{NH}_{3}-\mathrm{N}$ concentration was dependent on whether rate of bacterial protein synthesis or rate of dry matter degradation was the dependent variable.

We hypothesized that a portion of the variation between estimates of optimal rumen $\mathrm{NH}_{3}-\mathrm{N}$ concentration, which were based on experiments with mixed populations of rumen microbes, could be attributed to the types of degradable substrates provided. Maize has been used in some experiments (Hume et al. 1970; Satter \& Slyter, 1974; Ortega et al. 1979;

* For reprints. 
Slyter et al. 1979; Kang-Meznarich \& Broderick, 1981), barley in others (Mehrez et al. 1977; Wallace, 1979) and a combination of maize and barley in others (Allen \& Miller, 1976; Pisulewski et al. 1981). Since barley has been associated with relatively high estimates of optimal rumen $\mathrm{NH}_{3}-\mathrm{N}$ concentration and since barley is more extensively digested in the rumen than maize (Waldo, 1973), we considered that rumen fermentability of cereal grains could be a factor affecting estimates of optimal rumen $\mathrm{NH}_{3}-\mathrm{N}$ concentration. This possibility was investigated in the experiment reported here using four processed grains as fermentable substrates. Rolled barley was chosen for ease of comparison with previous literature (Mehrez et al. 1977), ground barley and ground maize were selected to allow comparison of two grains nominally similar in physical form, and autoclaved maize was used to assess the importance of starch gelatinization.

\section{MATERIALS AND METHODS}

\section{Diets and animals}

Four mature Holstein steers, mean weight $610 \mathrm{~kg}$, were used. They were housed in an open-air barn in individual pens bedded with shredded bark. Each animal was surgically fitted with a $100 \mathrm{~mm}$ rumen cannula and was allowed a 4-week postoperative period to recover. During that time, the steers were accustomed to their first dietary treatments, and were conditioned to receive feed on an hourly basis from automatic feeders as described by Finner \& Baumgardt (1963). Dry-matter intakes were restricted (11 g/kg body-weight) to ensure complete food consumption each hour. The diets provided sufficient energy to support small weight gains throughout the experiment.

Two basal diets were formulated (Table 1) and given either unsupplemented or supplemented with ammonium acetate $\left(\mathrm{NH}_{4} \mathrm{Ac}\right)$. Levels of $\mathrm{NH}_{4} \mathrm{Ac}$ given ranged from 0 to $500 \mathrm{~g} /$ steer per d in $100 \mathrm{~g}$ increments, resulting in a total of twelve experimental diets.

Diets were mixed in two stages. First, the barley or maize grain was combined with the maize cobs in $700 \mathrm{~kg}$ batches and mixed in a horizontal mixer. The mixture was then subdivided and stored in $20 \mathrm{~kg}$ bags. Later, daily rations were prepared in a small Hobart mixer. To the grain-cob mixture was added a dry vitamin-mineral premix and an aqueous supplement containing $\mathrm{NH}_{4} \mathrm{Ac}$ and sodium sulphate (N:sulphur, 10:1) in volumes appropriate to give the desired level of $\mathrm{NH}_{4} \mathrm{Ac}$ in the ration. The rations were mixed weekly and stored in sealed plastic bags at $-10^{\circ}$ until used.

\section{Design}

The four steers were given the diets according to a cross-over, split plot design. Animals were randomly assigned a basal diet in period 1 and were switched to the other basal diet during period 2 . Within each period, five $\mathrm{NH}_{4}$ Ac levels were randomly assigned after the unsupplemented basal diets were fed in the first subperiod, giving six subplots. During period 1, the same $\mathrm{NH}_{4} \mathrm{Ac}$ randomization was applied to steer nos. 1 and 3 (in sequence of $0,400,100,300,500$ and $200 \mathrm{~g} \mathrm{NH}_{4} \mathrm{Ac} / \mathrm{d}$ ) and to steer nos. 2 and 4 (in sequence of 0 , $100,500,400,200$ and $300 \mathrm{~g} \mathrm{NH}_{4} \mathrm{Ac} / \mathrm{d}$ ), while in period 2, steer nos. 1 and 4 (in sequence of $0,300,200,400,500$ and $100 \mathrm{~g} \mathrm{NH}_{4} \mathrm{Ac} / \mathrm{d}$ ) and steer nos. 2 and 3 (in sequence of 0,200 , $400,300,100$ and $500 \mathrm{~g} \mathrm{NH}_{4} \mathrm{Ac} / \mathrm{d}$ ) received the same sequence of $\mathrm{NH}_{4} \mathrm{Ac}$ treatments.

While only two basal diets were given, four grain treatments designated rolled barley, ground barley, ground maize and autoclaved maize were used for dacron-bag incubations in the rumen. During each subperiod, both barley treatments were incubated in the rumen of steers given the barley basal diet. Likewise, both maize treatments were incubated in the rumen of each steer fed on the maize basal diet. 
Table 1. Composition ( $\mathrm{g} / \mathrm{kg}$ dry matter) of basal diets to which graded amounts of ammonium acetate were added

\begin{tabular}{lcc}
\hline Ingredient & Barley diet & Maize diet \\
\hline Barley, rolled & 738.0 & - \\
Maize, cracked & - & 731.0 \\
Maize cobs, ground & $250 \cdot 0$ & 250.0 \\
Calcium carbonate & 6.8 & 5.2 \\
Dicalcium phosphate & - & 5.2 \\
Potassium chloride & 0.9 & 4.3 \\
Trace mineral salt* & 2.8 & 2.8 \\
Vitamin premix ${ }^{*}$ & 1.5 & 1.5 \\
\hline
\end{tabular}

* Trace mineralized salt composition $(\mathrm{g} / \mathrm{kg}$ ) was a minimum of $3.5 \mathrm{Zn}, 2.0 \mathrm{Mn}, 2.0 \mathrm{Fe}, 0.3 \mathrm{Cu}, 0.05 \mathrm{Co}, 0.07$ I and $\mathrm{NaCl}$ between 960 and 985 .

$\dagger$ Contained $(\mathrm{mg} / \mathrm{g}): 1.21$ vitamin A palmitate, 0.055 vitamin $\mathrm{D}_{3}, 0.22$ vitamin $\mathrm{E}$.

\section{Experimental protocol}

Animals were allowed to adapt to their basal diets for at least 3 weeks before the initiation of each period. The $42 \mathrm{~d}$ periods were each subdivided into six subperiods each $7 \mathrm{~d}$ long. During the first $6 \mathrm{~d}$ of each subperiod, steers were allowed to adapt to the level of $\mathrm{NH}_{4} \mathrm{Ac}$ in the diet before experimental measurements were made.

In a preliminary experiment with one animal, the level of $\mathrm{NH}_{4} \mathrm{Ac}$ fed was raised from 0 to $500 \mathrm{~g} / \mathrm{d}$, and rumen $\mathrm{NH}_{3}-\mathrm{N}$ concentration was monitored for $10 \mathrm{~d}$. The $\mathrm{NH}_{4} \mathrm{Ac}$ was then removed and rumen $\mathrm{NH}_{3}-\mathrm{N}$ concentration was monitored for another $10 \mathrm{~d}$. The results indicated that $6 \mathrm{~d}$ were more than sufficient for rumen $\mathrm{NH}_{3}-\mathrm{N}$ concentration to reach a new steady-state after a dietary perturbation. This preliminary experiment also indicated the importance of controlling water intake when attempting to establish a steady-state rumen $\mathrm{NH}_{3}-\mathrm{N}$ concentration. Therefore, on days 5 and 6 of each subperiod, voluntary water consumption was determined and averaged for each steer. On the 7 th day, steers were tethered and access to water was denied. Average daily water consumption of each steer was divided into nine equal portions, one of which was poured into the rumen at each sampling time.

At $08 \cdot 00$ hours on day 7 of each subperiod, eight polyethylene bottles with bags attached were soaked in water for $1 \mathrm{~min}$ and subsequently placed in the ventral rumen of each steer. One bottle was removed from each steer after $2,4,7,10,13,16,19$ and $22 \mathrm{~h}$ of rumen incubation. At each sampling time, approximately $400 \mathrm{ml}$ ventral rumen fluid were obtained and immediately placed on ice. One portion of the steer's water allowance was then poured into the rumen.

\section{Incubated grains}

The barley grain (Glenn variety) used for the incubation measurements was harvested from the agronomic plots of the University of Wisconsin-Madison and held in dry storage for 1 year before being used in this experiment. A portion of the barley was processed through a small roller mill. Kernels that were not crushed were sorted out, and the remaining rolled grain comprised the rolled barley treatment. A second portion of the whole grain was ground through a $6 \mathrm{~mm}$ screen and mechanically sieved for $3 \mathrm{~min}$. Of the ground grain $4 \%$ passed through a 40-mesh screen and was discarded. Grain fragments larger than 40 mesh were recombined and mixed in a Hobart mixer for $2 \mathrm{~min}$, resulting in the ground barley treatment. 
The maize grain used was of the Trelay 8000 variety (Trelay Farms, Livingston, Wisconsin). For the ground-maize treatment, the grain was processed in exactly the same manner as the ground barley. Of the weight before sieving, $9 \%$ passed through the 40 -mesh screen and was discarded as fines. The autoclaved maize was prepared by submerging whole maize in water and autoclaving at $121^{\circ}$ for $30 \mathrm{~min}$. Excess water was drained off and the wet maize remaining was spread out in broad-based pans and dried at $65^{\circ}$ in a forced-air oven for $24 \mathrm{~h}$. This material was then ground and sieved through a 40 -mesh screen as described earlier; fines comprised $5 \%$ of presieved weight.

\section{Dacron-bag technique}

Dacron cloth (Erlanger Baumgardt \& Co., New York), with a pore size of 4000 (SD 1450) $\mu \mathrm{m}^{2}$, was cut and sewn into bags with internal dimensions of $80 \times 55 \mathrm{~mm}$. Seams were double stitched and the stitch holes were filled by applying glue (Duco cement; Devcon Corp., Danvers, Maine) to the seams. The mouth of each bag was singed with a flame to prevent fraying. Bags were inverted and dried at $65^{\circ}$ in a forced-air oven for $24 \mathrm{~h}$. After standing in a desiccator for at least $3 \mathrm{~h}$, they were weighed to the nearest $0.0002 \mathrm{~g}$ and were filled with approximately $2 \mathrm{~g}$ air-dry grain sample with equal precision. This resulted in a value for the ratio, substrate: bag surface area, of $0.227 \mathrm{mg} / \mathrm{mm}^{2}$.

The mouths of the bags were tied shut with non-sterile surgical suture (Ethicon no. 0; Ethicon Inc., Somerville, New Jersey). Polyethylene bottles $(125 \mathrm{ml})$ filled with $0.5 \mathrm{~kg}$ lead shot were used to weight the bags. A total of six bags, either three rolled barley plus three ground barley, or three ground maize plus three autoclaved maize, were attached to each bottle.

Wohlt et al. (1976) have shown that rumen $\mathrm{NH}_{3}-\mathrm{N}$ concentration is higher in the dorsal portion than in the ventral portion of the rumen. Thus, weighting the bags was designed to ensure that they were confined to the ventral portion of the rumen so that the $\mathrm{NH}_{3}-\mathrm{N}$ concentration determined in that region would represent the concentration in the fluid surrounding the bags.

After bottles were removed from the rumen, bags were submerged in ice-cold water for $2 \mathrm{~h}$, after which they were cut from the bottles. Any feed residue on the exterior of the bags was removed, and the excess water in the bags was gently expressed. Bags were subsequently dried at $65^{\circ}$, placed in a desiccator for $3 \mathrm{~h}$ and weighed.

\section{Sample preparation and chemical analysis}

The $\mathrm{pH}$ of the chilled rumen fluid samples was determined with a combination glass electrode, and the samples were strained through one layer of cheese-cloth. Approximately $30 \mathrm{ml}$ were centrifuged at $43500 \mathrm{~g}$ for $10 \mathrm{~min}$ at $4^{\circ}$ to remove feed particles, protozoa and bacteria. Microscopic examination of the supernatant fraction revealed that only a few very small bacteria remained. Of the supernatant fraction, $10 \mathrm{ml}$ from each sample were acidified with $2 \mathrm{ml}$ metaphosphoric acid $(250 \mathrm{~g} / \mathrm{l})$ for $\mathrm{NH}_{3}-\mathrm{N}$ determination. In addition, $5 \mathrm{ml}$ of the supernatant fraction from each steer were saved at each sampling time and mixed to form a composite sample for each steer on each collection day. Of each composite, $10 \mathrm{ml}$ were acidified with $2 \mathrm{ml}$ metaphosphoric acid $(250 \mathrm{~g} / \mathrm{l})$ for VFA analysis. All samples were stored at $-10^{\circ}$ until analysed.

The four grains to be incubated in dacron bags were analysed for crude protein $(\mathrm{N} \times 6.25)$ using a modified micro-Kjeldahl procedure (Bradstreet, 1965; Brotz \& Schaefer, 1984). Neutral- and acid-detergent fibre contents were determined according to the procedures of Goering \& Van Soest (1970), and $\alpha$-linked glucose polymers by the method of MacRae \& Armstrong (1968) using glucan 1, 4- $\alpha$-glucosidase (amyloglucosidase; EC 3.2.1.3) from Rhizopus fungi. 
Frozen samples of rumen fluid were thawed at room temperature and blown through a sintered-glass filter to remove precipitated protein. $\mathrm{NH}_{3}-\mathrm{N}$ concentrations were determined in the samples using the Berthelot colorimetric reaction described by Chaney \& Marbach (1962) and the phenol and hypochlorite reagents reported by Brotz \& Schaefer (1984). VFA were separated and quantified by gas-liquid chromatography (Supelco, 1975).

\section{Statistical methods}

Analysis of rumen variables. Basal diet and $\mathrm{NH}_{4} \mathrm{Ac}$ effects on rumen fluid $\mathrm{pH}, \mathrm{NH}_{3}-\mathrm{N}$ concentrations and molar proportions of VFA were analysed according to a cross-over, split plot analysis of variance (Cochran \& Cox, 1957). All main effect means were separated with Duncan's new multiple-range test (Steel \& Torrie, 1980).

Fractional degradation rate computation. The disappearance of dry matter from the bags over time was fitted to a single-pool exponential decay model described as follows:

$$
\mathrm{DMR}=A \mathrm{e}^{-K_{d} t}
$$

where DMR is dry matter remaining in the bag (proportion of initial), $A$ is dry matter remaining at time zero, $K_{d}$ is fractional rate of dry matter disappearance $(/ \mathrm{h})$, and $t$ is period of rumen incubation $(\mathrm{h})$.

The equation was linearized by natural $\log$ transformation $\left(\ln \mathrm{DMR}=\ln A-K_{d} t\right)$ and each $K_{d}$ was estimated by regression. Residual analysis revealed that the error variance was heterogeneous, increasing with length of incubation. Therefore, weighted least squares regression (Neter \& Wasserman, 1974) was employed to stabilize the error variance. Each of the ninety-six disappearance curves was linearized as described and individually examined for remaining curvature by testing for the significance of a $t^{2}$ term; $24 \%$ contained significant curvature $(P<0.05)$. Further examination of the residuals showed that the results obtained at $2 \mathrm{~h}$ of incubation were consistently adding curvature to the relation for each grain. For this reason, these values were discarded, and the extent of curvature was reassessed. Only $10 \%$ of the relations then contained significant $t^{2}$ effects, and this could not be improved.

Analysis of fractional degradation rates. In a preliminary analysis, $K_{d}$ estimates were subjected to an analysis of variance, removing effects due to animal, period, grain and the animal $\times$ period $\times$ grain interaction. Residuals from this analysis were plotted against rumen $\mathrm{NH}_{3}-\mathrm{N}$ concentration for each substrate separately. The plateau and exponential models described by Mehrez et al. (1977) were then fitted to each of the four scatter plots by the method of least squares (SAS Institute, 1982). A general extra sum of squares test (Neter \& Wasserman, 1974) indicated that the rolled and ground barley models did not differ $(P>0 \cdot 10)$. A similar conclusion was reached for the two maize substrates. Hartley's test (Neter \& Wasserman, 1974) indicated that the error variance was greater for the combined barley regression than for the combined maize regression so that for the final analysis the two grain types were analysed separately.

In the final $K_{d}$ analysis each data set was submitted to the non-linear procedure of the Statistical Analysis System (SAS Institute, 1982). The chosen model included terms for animal effects and rumen $\mathrm{NH}_{3}-\mathrm{N}$ concentration as either a plateau or exponential effect. The fitted models were then adjusted to the average animal and the resultant plateau and exponential equations were plotted. The residual for each $K_{d}$ observation was added to the value predicted by the plateau model to obtain the scatter plots. A $t$ test was then used to examine the difference between $x$ coordinates of the plateau breakpoints (optimal rumen $\mathrm{NH}_{3}-\mathrm{N}$ concentrations) and all other parameter estimates for barley and maize, considering the error variances of the estimates from the two grains to be unequal. 
Table 2. Chemical composition $(\mathrm{g} / \mathrm{kg})$ of grains incubated in the ventral rumen of steers fed on barley or maize basal diets supplemented with graded amounts of ammonium acetate

\begin{tabular}{lcrrr}
\hline Component & $\begin{array}{c}\text { Rolled } \\
\text { barley }\end{array}$ & $\begin{array}{c}\text { Ground } \\
\text { barley }\end{array}$ & $\begin{array}{c}\text { Ground } \\
\text { maize }\end{array}$ & $\begin{array}{c}\text { Autoclaved } \\
\text { maize }\end{array}$ \\
\hline Dry matter & 924 & 914 & 891 & 875 \\
Crude protein (nitrogen $\times 6 \cdot 25)^{*}$ & 120 & 118 & 89 & 90 \\
Starch* & 520 & 550 & 740 & 760 \\
Neutral-detergent fibre* & 223 & 244 & 108 & 105 \\
Acid-detergent fibre* & 83 & 69 & 24 & 29 \\
\hline
\end{tabular}

* Dry matter basis.

Table 3. Volatile fatty acid (VFA) concentration and composition, $p H$ and ammonianitrogen in ventral rumen fluid of steers fed on maize or barley diets supplemented with ammonium acetate $\left(\mathrm{NH}_{4} \mathrm{Ac}\right)$

\begin{tabular}{|c|c|c|c|c|c|c|c|}
\hline & \multirow{2}{*}{$\begin{array}{l}\text { VFA concen- } \\
\text { tration }(\mathrm{mM})\end{array}$} & \multicolumn{4}{|c|}{ VFA composition ( $\mathrm{mmol} / \mathrm{mol}$ VFA) } & \multirow[b]{2}{*}{$\mathrm{pH}$} & \multirow{2}{*}{$\begin{array}{c}\mathrm{NH}_{3}-\mathrm{N} \\
(\mathrm{mg} / \mathrm{l})\end{array}$} \\
\hline & & Acetic & Propionic & Butyric & Other* & & \\
\hline Maize & $102 \cdot 3$ & $673^{a}$ & 183 & 101 & 44 & $6 \cdot 46$ & $92 \cdot 8^{\mathfrak{a}}$ \\
\hline Barley & $104 \cdot 7$ & $655^{\mathrm{b}}$ & 172 & 129 & 44 & $6 \cdot 41$ & $159 \cdot 7^{\mathrm{b}}$ \\
\hline $\mathrm{SE}$ & $1 \cdot 5$ & 1 & 2 & 2 & 1 & 0.04 & $2 \cdot 0$ \\
\hline \multicolumn{8}{|l|}{$\begin{array}{c}\mathrm{NH}_{4} \mathrm{Ac} \\
(\mathrm{g} / \mathrm{d})\end{array}$} \\
\hline 000 & $88 \cdot 6^{\mathrm{a}}$ & $642^{a}$ & 182 & 132 & 44 & 6.49 & $41 \cdot 0^{\mathrm{a}}$ \\
\hline 100 & $100 \cdot 8^{b}$ & $657^{a, b}$ & 181 & 114 & 48 & 6.40 & $79 \cdot 6^{\mathrm{b}}$ \\
\hline 200 & $107 \cdot 6^{\mathrm{b}}$ & $678^{\mathrm{b}}$ & 166 & 112 & 44 & $6 \cdot 46$ & $110 \cdot 6^{\mathrm{b}}$ \\
\hline 300 & $109 \cdot 7^{\mathrm{b}}$ & $662^{a, b}$ & 180 & 114 & 45 & $6 \cdot 41$ & $145^{\circ} 7^{c}$ \\
\hline 400 & $108 \cdot 2^{\mathrm{b}}$ & $675^{b}$ & 174 & 111 & 40 & 6.42 & $173 \cdot 4^{\mathrm{c}, \mathrm{d}}$ \\
\hline 500 & $106 \cdot 1^{\mathrm{b}}$ & $668^{\mathrm{b}}$ & 182 & 107 & 43 & 6.43 & $207 \cdot 3^{d}$ \\
\hline $\mathrm{SE}$ & $3 \cdot 6$ & 2 & 2 & 2 & 1 & 0.04 & $3 \cdot 5$ \\
\hline
\end{tabular}

a, b, c, a Values with different superscript letters differed significantly (Duncan's new multiple-range test): $P<0.05$. The error term for diet effects was the animal $\times$ period $\times$ diet interaction $(2 \mathrm{df})$ and the error term for the $\mathrm{NH}_{4} \mathrm{Ac}$ main effect was the residual error ( $\left.10 \mathrm{df}\right)$.

* Sum of iso-butyric, valeric and iso-valeric acids.

\section{RESULTS}

The chemical composition of the incubated grains is shown in Table 2. The composition of the barley samples differed markedly from the maize samples, being higher in crude protein and fibre but lower in starch content. Processing of grains had no effect on their chemical composition.

The effects of basal diet and $\mathrm{NH}_{4} \mathrm{Ac}$ on rumen VFA concentrations, $\mathrm{pH}$ and $\mathrm{NH}_{3}-\mathrm{N}$ concentration are summarized in Table 3 . The major difference detected between the basal diets was with respect to rumen $\mathrm{NH}_{3}-\mathrm{N}$ concentration which was higher $(P<0.05)$ for the barley diet $(159.7 \mathrm{mg} / \mathrm{l})$ than for the maize diet $(92.8 \mathrm{mg} / 1)$. This difference was expected since the barley basal diet contained more crude protein than the maize diet. There was also a slightly lower proportion of acetate associated with the barley diet. Total VFA 
Table 4. Rumen ammonia-nitrogen concentrations $(\mathrm{mg} / \mathrm{l})$ in steers fed on barley or maize diets supplemented with graded amounts of ammonium acetate

(Mean values and standard deviations for eight sampling times)

\begin{tabular}{|c|c|c|c|c|c|}
\hline \multirow[b]{2}{*}{ Animal no. } & \multirow{2}{*}{$\begin{array}{l}\text { Ammonium } \\
\text { acetate } \\
\text { (g/d) }\end{array}$} & \multicolumn{2}{|c|}{ Barley diet } & \multicolumn{2}{|c|}{ Maize diet } \\
\hline & & Mean & SD & Mean & SD \\
\hline \multirow[t]{6}{*}{1} & 000 & 52 & 17 & 6 & 2 \\
\hline & 100 & 114 & 17 & 43 & 7 \\
\hline & 200 & 151 & 32 & 73 & 34 \\
\hline & 300 & 165 & 36 & 136 & 63 \\
\hline & 400 & 231 & 47 & 141 & 41 \\
\hline & 500 & 209 & 34 & 160 & 32 \\
\hline \multirow[t]{6}{*}{2} & 000 & 68 & 16 & 45 & 12 \\
\hline & 100 & 97 & 15 & 39 & 20 \\
\hline & 200 & 146 & 27 & 58 & 21 \\
\hline & 300 & 228 & 28 & 93 & 25 \\
\hline & 400 & 208 & 31 & 154 & 31 \\
\hline & 500 & 275 & 33 & 155 & 39 \\
\hline \multirow[t]{6}{*}{3} & 000 & 87 & 16 & 13 & 4 \\
\hline & 100 & 146 & 17 & 47 & 9 \\
\hline & 200 & 125 & 16 & 107 & 20 \\
\hline & 300 & 152 & 26 & 135 & 34 \\
\hline & 400 & 170 & 37 & 134 & 30 \\
\hline & 500 & 204 & 36 & 158 & 28 \\
\hline \multirow[t]{6}{*}{4} & 000 & 39 & 10 & 18 & 3 \\
\hline & 100 & 128 & 38 & 23 & 21 \\
\hline & 200 & 142 & 33 & 83 & 5 \\
\hline & 300 & 124 & 25 & 133 & 47 \\
\hline & 400 & 253 & 82 & 96 & 20 \\
\hline & 500 & 320 & 38 & 177 & 50 \\
\hline
\end{tabular}

concentration and the molar proportion of acetic acid were higher $(P<0.05)$ in the second experimental period (109.5 mM and $668 \mathrm{mmol} / \mathrm{mol}$ VFA, respectively) than for the first $(97.5 \mathrm{~mm}$ and $659 \mathrm{mmol} / \mathrm{mol} \mathrm{VFA})$. This increase may have been due to the increased feeding levels required in the second period to maintain the level of dry-matter consumption at $11 \mathrm{~g} / \mathrm{kg}$ body-weight.

Rumen $\mathrm{NH}_{3}-\mathrm{N}$ concentration steadily increased with increased $\mathrm{NH}_{4} \mathrm{Ac}$ supplementation. However, only minor differences in total VFA concentration and molar proportion of acetic acid were observed. Interactions between $\mathrm{NH}_{4} \mathrm{Ac}$ and the whole plot factors were not significant $(P>0 \cdot 05)$.

Average rumen $\mathrm{NH}_{3}-\mathrm{N}$ concentrations measured at each level of $\mathrm{NH}_{4} \mathrm{Ac}$ supplementation for each animal given each basal diet are shown in Table 4 . The relatively low standard deviations (range of $2-82 \mathrm{mg} \mathrm{NH} \mathrm{NH}_{3}-\mathrm{N} / \mathrm{l}$ ) indicated that reasonable steady-state conditions were maintained during sample collection. However, a plot of rumen $\mathrm{NH}_{3}-\mathrm{N}$ concentration, adjusted to remove whole and subplot effects, $v$. sampling time showed a significant $(P<0.05)$ diurnal pattern (Fig. 1$)$.

The relation between rumen $\mathrm{NH}_{3}-\mathrm{N}$ concentration and the adjusted fractional degradation rates of barley and maize is shown in Fig. 2. Parameter estimates for the plateau and exponential models displayed in Fig. 2 are given in Table 5. Differences in the mean degradation rates for rolled and ground barley treatments were not detected $(P>0 \cdot 10)$ and since the extra sum of squares test indicated that the effect of rumen $\mathrm{NH}_{3}-\mathrm{N}$ concentration 


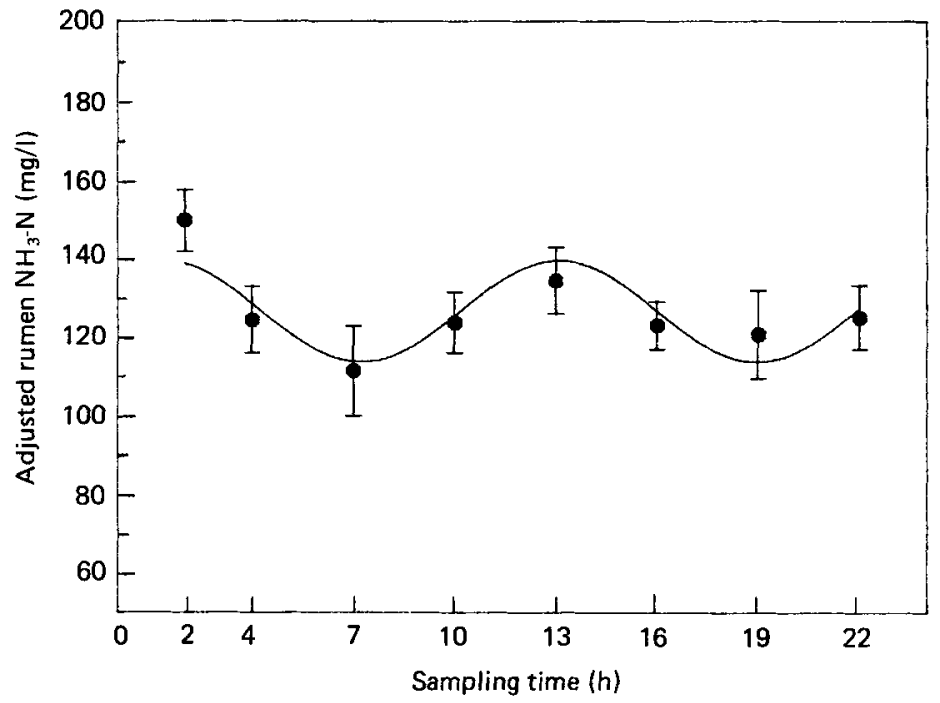

Fig. 1. Diurnal pattern of rumen ammonia-nitrogen (adjusted to remove whole and subplot effects) concentration in steers fed hourly. Zero-hour sampling time was 08.00 hours. $y=12.9 \sin$ $(0 \cdot 54(x-10 \cdot 15))+126 \cdot 4$. Each point is the mean, with 2 SE represented by vertical bars, for forty-eight observations.

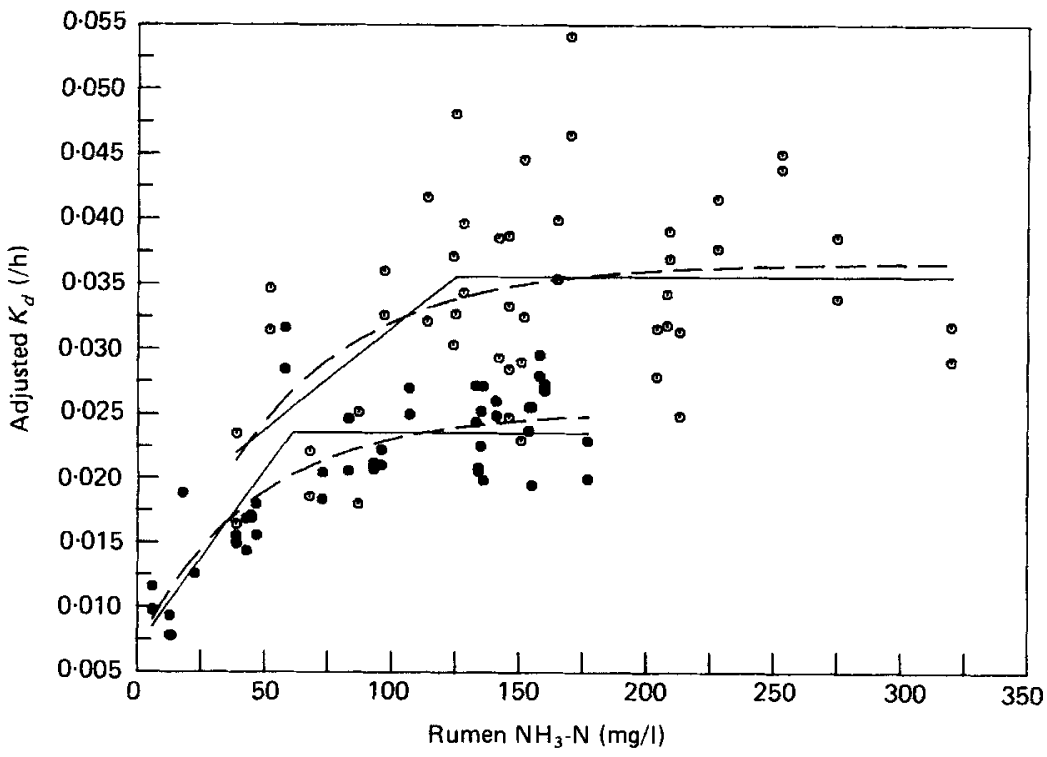

Fig. 2. Relation between rumen ammonia-nitrogen concentration and fractional degradation rates $\left(K_{d}\right.$; adjusted to the average animal effect) for barley $(\odot)$ and maize $(\odot)$ dry matter in dacron bags suspended in the ventral rumen of steers. See Table 5 for parameter estimates of the plateau and exponential models which have been plotted. The $x$ coordinates of the plateau breakpoint for barley and maize models are 125 and $61 \mathrm{mg} \mathrm{NH}-\mathrm{N} / 1$ respectively $(P<0.05)$. 
Table 5. Parameter estimates of the plateau and exponential models which describe the effect of rumen ammonia-nitrogen concentration on adjusted $\mathrm{K}_{\mathrm{d}}$ for barley and maize

\begin{tabular}{llccccccc}
\hline \multirow{2}{*}{ Model } & & \multicolumn{7}{c}{ Parameter } \\
\cline { 3 - 7 } & Grain & $A$ & SE & $B$ & SE & $C$ & SE \\
\hline Plateau* & Barley & 0.00016 & 0.00007 & $125^{\mathrm{a}}$ & 23 & $0.036^{\mathrm{a}}$ & 0.0013 \\
& Maize & 0.00028 & 0.00006 & $61^{\mathrm{b}}$ & 7 & $0.024^{\mathrm{b}}$ & 0.0007 \\
Exponential $\dagger$ & Barley & $0.037^{\mathrm{a}}$ & 0.0023 & -0.034 & 0.023 & 0.021 & 0.014 \\
& Maize & $0.024^{\mathrm{b}}$ & 0.0017 & -0.018 & 0.002 & 0.020 & 0.007 \\
\hline
\end{tabular}

a,b For the model given, parameter estimates with different superscript letters differed significantly $(P<0 \cdot 05)$ for barley and maize.

$K_{d}$, fractional rate of dry-matter disappearance $(/ \mathrm{h})$.

* The plateau model has the form: $y=\gamma+A x$ for $x<B$, and $y=C$ for $x \geqslant B$, where $\gamma=(C-A B)$.

$\dagger$ The exponential model has the form: $y=A+B \mathrm{e}^{-C x}$.

was similar for both, the rolled and ground barley treatments were pooled. The same was true for the ground- and autoclaved-maize treatments. Plateau models fitted the values better than exponential models as indicated by smaller residual sums of squares. Rumen $\mathrm{NH}_{3}-\mathrm{N}$ concentration for the barley diets ranged from 39 to $320 \mathrm{mg} / \mathrm{l}$, while the maize diets ranged from 6 to $177 \mathrm{mg} / \mathrm{l}$. A difference between slopes of the ascending portions of the barley and maize plateau models was not detected $(P>0 \cdot 10)$. The maximum degradation rate for barley grain was greater than that for maize $(0.036 v .0 .024 / \mathrm{h}$ respectively; $P<0.01)$. Furthermore, the minimum rumen $\mathrm{NH}_{3}-\mathrm{N}$ concentration required to maximize the degradation rate of maize was 61 (SE 7.3$) \mathrm{mg} / 1$ which was lower $(P<0.05)$ than the 125 (SE $23 \cdot 6) \mathrm{mg} / \mathrm{l}$ concentration required to maximize the rate for barley.

\section{DISCUSSION}

It has been suggested (Van Soest, 1982) that the single-pool exponential decay model used to describe forage dry matter remaining in dacron bags over time may fit better if the undegradable dry matter fraction is estimated and subtracted from each observation. This correction would help approach the single-pool assumption. However, in a preliminary investigation with barley and maize samples, we determined that this correction did not noticeably improve the fit of the model to our findings and therefore it was not utilized in this experiment. Quadratic effects present after the natural log transformation suggested that the correction may have been necessary; however, curvature introduced by the values for the $2 \mathrm{~h}$ period of incubation contributed substantially. After removal of the $2 \mathrm{~h}$ values, many of the plots of $\ln$ DMR $v$. time with significant $t^{2}$ effects showed negative quadratic relations. This remaining curvature was considered to result from lack of precision in the intrarumen incubation technique rather than effects due to a second pool.

Precision of the dacron-bag technique is limited by the large number of factors which can influence dry-matter disappearance (Figroid et al. 1972; Meyer \& Mackie, 1986). A specific problem encountered with the high-grain diets used in this experiment was accumulation of gas in the bags. Gas accumulation has been reported by others (Lowrey, 1970; Uden \& Van Soest, 1984). Increased rumen fluid viscosity in grain-fed animals may provoke occlusion of pores in the dacron material. Likewise, incubation in the highly fluid ventral rumen may prevent the gas from being expressed.

An absorption method similar to that described by Mehrez et al. (1977) was used to 
supplement the basal diets with an $\mathrm{NH}_{4} \mathrm{Ac}-\mathrm{Na}_{2} \mathrm{SO}_{4}$ solution, thereby avoiding technical difficulties associated with continuous rumen infusions. Hourly feeding of the supplemented diets assisted in achieving steady-state rumen $\mathrm{NH}_{3}-\mathrm{N}$ concentrations. However, additional control over water consumption improved the steady-state approximation markedly. Although these efforts were reasonably effective in stabilizing rumen $\mathrm{NH}_{3}-\mathrm{N}$ concentration (Table 4), a diurnal fluctuation was still detectable (Fig. 1).

Wohlt et al. (1976) observed an increase in rumen $\mathrm{NH}_{3}-\mathrm{N}$ concentration beginning at 01.00 hours which was $9.5 \mathrm{~h}$ after the previous feeding. They attributed this, in part, to previously reported post-prandial patterns of saliva secretion (Bailey \& Balch, 1961; Meyer et al. 1964) and reasoned that influx of salivary urea into the rumen accounted for increased $\mathrm{NH}_{3}-\mathrm{N}$ concentrations. Post-prandial patterns of saliva secretion are not sufficient to explain the present results since the data were collected from steers fed hourly and given their daily water allowance in nine equal intrarumen doses. These results suggest that there was an underlying diurnal pattern to rumen $\mathrm{NH}_{3}-\mathrm{N}$ concentration which was not suppressed by hourly meal consumption. This resilient characteristic could be caused by diurnal patterns of rumination, salivation independent of rumination, or transrumen flux of urea-N.

The use of $\mathrm{NH}_{4} \mathrm{Ac}$ as the supplemental non-protein- $\mathrm{N}$ source had the desired effect of increasing rumen $\mathrm{NH}_{3}-\mathrm{N}$ concentration without adversely affecting $\mathrm{pH}$, which could be a confounding factor when urea supplements are given. Furthermore, acetate was selected as the associated anion based on the consideration that it would have little influence on the large rumen acetate pool.

No differences in mean dry-matter degradation rates were detected between processing methods for each grain type. Similarly, the relation between rumen $\mathrm{NH}_{3}-\mathrm{N}$ concentration and degradation rate (Fig. 2) was not significantly affected by grain-processing method. Chemical analyses revealed that processing did not alter composition, but autoclaving should have increased the fermentability of the maize starch. In subsequent experimentation, $100 \mathrm{mg}$ ground and autoclaved maize were exposed for $1-5 \mathrm{~h}$ to Rhizopus glucan 1, 4- $\alpha$-glucosidase. Rates of glucose appearance were not different $(P>0 \cdot 10)$ for the two maize treatments. This implies that the gelatinized starch content of the autoclaved maize used for intrarumen incubations may not have been as high as intended. Exposure of maize to dry heat after autoclaving may have offset any increase in starch degradability due to autoclaving.

The minimum rumen $\mathrm{NH}_{3}-\mathrm{N}$ concentration required to maximize the fractional degradation rate of barley exceeded that for maize (Fig. 2). This suggests that the optimal rumen $\mathrm{NH}_{3}-\mathrm{N}$ concentration is higher for barley than for maize diets. Caution should be exercised, however, since the barley values refer to a higher rumen $\mathrm{NH}_{3}-\mathrm{N}$ concentration range than the maize values. Nevertheless, chemical or structural characteristics of the degradable substrate may influence estimates of optimal rumen $\mathrm{NH}_{3}-\mathrm{N}$ concentration, and this may in part explain the divergent estimates occurring in the literature.

The $\mathrm{NH}_{3}$ saturation constants estimated for predominant species of rumen bacteria (Schaefer et al. 1980) indicate that lower concentrations than those reported here should support maximum bacterial growth rates. However, those results were obtained with bacterial suspensions grown in media without substrates for attachment. It is tempting to speculate that the relatively high estimates of optimal rumen $\mathrm{NH}_{3}-\mathrm{N}$ concentration obtained in vivo are due to the physical association of bacterial celis with fermentable substrates. This speculation invokes the earlier suggestion (Allison, 1969; Ørskov, 1982; Owens \& Bergen, 1983) that localized concentrations of nutrients or metabolites in micro-habitats could influence microbial growth and metabolism.

The extent of bacterial attachment may vary in direct proportion with the fermentability 
of grains and this could enhance differences in concentrations of soluble nutrients or metabolites between the microenvironments within attached bacterial strata and the suspending milieu. Maize is less extensively digested in the rumen and is associated with relatively low estimates of optimal rumen $\mathrm{NH}_{3}-\mathrm{N}$ concentration (Satter \& Slyter, 1974; Slyter et al. 1979; Kang-Meznarich \& Broderick, 1981) while barley is extensively degraded in the rumen and was a diet component or an incubated feed in reports of relatively high optimal rumen $\mathrm{NH}_{3}-\mathrm{N}$ concentration (Allen \& Miller, 1976; Mehrez et al. 1977; Wallace, 1979).

Another possible explanation is that specific dietary components give rise to antimetabolites of $\mathrm{NH}_{3}-\mathrm{i}$. Methylamine has been reported to inhibit the extent of $\mathrm{NH}_{3}-\mathrm{N}$-limited growth of Bacteroides amylophilus (Ricke \& Schaefer, 1984).

The authors wish to express their gratitude to Dr Mark Thornquist for his expert statistical counsel and to Ms Melanie Jo Fron for her technical assistance. This research was funded by Hatch project 2629 of the College of Agricultural and Life Sciences, University of Wisconsin-Madison; a fellowship from the University of Wisconsin-Madison Graduate School; and a scholarship from the Universal Foods Corporation, Milwaukee, Wisconsin. This is paper no. 876 from the Department of Meat and Animal Science.

\section{REFERENCES}

Allen, S. A. \& Miller, E. L. (1976). British Journal of Nutrition 36, 353-368.

Allison, M. J. (1969). Journal of Animal Science 29, 797-807.

Bailey, C. B. \& Balch, C. C. (1961). British Journal of Nutrition 15, 183.

Bradstreet, R. B. (1965). The Kjeldahl Method for Organic Nitrogen, pp. 40-42. New York: Academic Press.

Brotz, P. G. \& Schaefer, D. M. (1984). Journal of Animal Science 59, Suppl. 1, 408.

Bryant, M. P. \& Robinson, I. M. (1962). Journal of Bacteriology 84, 605-614.

Chaney, A. L. \& Marbach, E. P. (1962). Clinical Chemistry 8, 130-132.

Cochran, W. G. \& Cox, G. M. (1957). Experimental Designs. New York: John Wiley \& Sons Inc.

Coleman, G. S. (1979). In Biochemistry and Physiology of Protozoa no. 2, pp. 381-408 [M. Levandowsky and S. H. Hunter, editors]. New York: Academic Press.

Figroid, W., Hale, W. H. \& Theurer, B. (1972). Journal of Animal Science 35, 113-120.

Finner, M. F. \& Baumgardt, B. R. (1963). Journal of Dairy Science 46, 341.

Goering, H. K. \& Van Soest, P. J. (1970). Agriculture Handbook no. 379. Washington DC: US Department of Agriculture.

Hume, I. D., Moir, R. J. \& Somers, M. (1970). Australian Journal of Agricultural Research 21, 283-296.

Kang-Meznarich, J. H. \& Broderick, G. A. (1981). Journal of Animal Science 51, 422-431.

Lowrey, R. S. (1970). Proceedings of the National Conference on Forage Quality Evaluation and Utilization, p. 12. Lincoln: University of Nebraska.

MacRae, J. C. \& Armstrong, D. G. (1968). Journal of the Science of Food and Agriculture 19, 578-581.

Mehrez, A. Z., Ørskov, E. R. \& McDonald, I. (1977). British Journal of Nutrition 38, 437-443.

Meyer, J. H. F. \& Mackie, R. I. (1986). Applied and Environmental Microbiology 51, 622-629.

Meyer, R. M., Bartley, E. E., Morrill, J. L. \& Stewart, W. E. (1964). Journal of Dairy Science 47, 1339-1345.

Neter, J. \& Wasserman, W. (1974). Applied Linear Statistical Models. Homewood, Illinois: Richard D. Irwin Inc.

Nikolic, J. A., Jovanovic, M. \& Filipovic, R. (1975). In Tracer Studies on Non-Protein Nitrogen for Ruminants, vol. 2, pp. 43-54. Vienna: International Atomic Energy Agency.

Ørskov, E. R. (1982). Protein Nutrition in Ruminants, p. 31. New York: Academic Press.

Ortega, M. E., Stern, M. D. \& Satter, L. D. (1979). Journal of Dairy Science 62, 76.

Owens, F. N. \& Bergen, W. G. (1983). Journal of Animal Science 57, 498-518.

Pisulewski, P. M., Okorie, A. U., Buttery, P. J., Haresign, W. \& Lewis, D. (1981). Journal of the Science of Food and Agriculture 32, 759-766.

Ricke, S. C. \& Schaefer, D. M. (1984). Journal of Animal Science 59, Suppl. 1, 408.

SAS Institute (1982). SAS User's Guide: Statistics. Cary, North Carolina: SAS Institute Inc.

Satter, L. D. \& Slyter, L. L. (1974). British Journal of Nutrition 32, 199-208.

Schaefer, D. M., Davis, C. L. \& Bryant, M. P. (1980). Journal of Dairy Science 63, 1248-1263.

Slyter, L. L., Satter, L. D. \& Dinius, D. A. (1979). Journal of Animal Science 48, 906-912.

Steel, R. D. G. \& Torrie, J. H. (1980). In Principles and Procedures of Statistics, pp. 187-188 [C. Napier and J. W. Maisel, editors]. New York: McGraw-Hill. 
Supelco (1975). GC Separation of VFA C2-C5. Bulletin 749E. Bellefonte, Pennsylvania: Supelco Inc. Uden, P. \& Van Soest, P. J. (1984). Journal of Animal Science 58, 213-221.

Van Soest, P. J. (1982). Nutritional Ecology of the Ruminant. Oregon: O \& B Books Inc.

Waldo, D. R. (1973). Journal of Animal Science 37, 1062-1074.

Wallace, R. J. (1979). Journal of Applied Bacteriology 47, 443-445.

Wohlt, J. E., Clark, J. H. \& Blaisdell, F. S. (1976). Journal of Dairy Science 59, 459-464. 